\title{
Combining ability of standardized indices for multi-trait selection in tobacco
}

\section{Capacidade de combinação de índices de seleção para seleção de vários caracteres em tabaco}

\author{
Bruna Line Carvalho' (D), Ramsey Lewis² (D), José Maria Villela Pádua ${ }^{3 *}$ (D), \\ Adriano Teodoro Bruzi ${ }^{3}$ (D) Magno Antonio Patto Ramalho ${ }^{4}$ (D)
}

'Bayer S.A., São Paulo, SP, Brasil

${ }^{2}$ NC State University, Raleigh, NC, United States of America

3Universidade Federal de Lavras/UFLA, Departamento de Agricultura/DAG, Lavras, MG, Brasil

${ }^{4}$ Universidade Federal de Lavras/UFLA, Departamento de Biologia/DBI, Lavras, MG, Brasil

*Corresponding author: jose.padua@ufla.br

Received in March 17, 2021 and approved in July 8, 2021

\begin{abstract}
Several traits must be simultaneously considered in selection of tobacco cultivars for meeting the requirements of farmers, manufacturers and consumers. Breeders should have an understanding of associations between economically-important traits in order to devise the best strategy to have response to selection for all them. Utilization of selection indices has been shown to be one of the most efficient strategy for selecting for correlated characters. In tobacco, no reports can be found within the academic literature for multiple trait selection. In this study we demonstrate the efficiency of the Sum of the Standardized Variables Index (SSV) for multi-trait selection in tobacco. The method was evaluated using a collection of thirteen inbred lines and hybrids derived using a diallel scheme. The hybrids, parental lines, and checks were evaluated in two field locations. The traits assessed were yield (YLD), general quality index (GQI), leaf stem to lamina ratio, percent total alkaloids, and percent total sugars. We considered weights according to the economic importance of each trait: 0.4 for YLD, 0.3 for GQI and 0.1 for the remaining characters. The SSV index proved to be efficient and easy to interpret, and could be used to generate genetic gain for almost all characters in the desired direction. General combining ability (GCA) explained the larger part of the variation of the index in the diallel analysis. The mean heterosis estimate was $2.02 \%$. Some hybrid combinations exhibited heterosis levels greater than $10 \%$, indicating that increased attention might need to be given to commercialization of $F_{1}$ hybrids.
\end{abstract}

Index terms: Plant breeding; quantitative genetics; heterosis.

\begin{abstract}
RESUMO
Várias características devem ser consideradas simultaneamente na seleção de cultivares de tabaco para atender às necessidades dos agricultores, fabricantes e consumidores. Nesse contexto os melhoristas devem conhecer as correlações entre as características de importância econômica, a fim de adotar a melhor estratégia de seleção para elas. A utilização de índices de seleção tem se mostrado uma das estratégias mais eficientes para selecionar caracteres correlacionados. No caso do tabaco, nenhum relato foi encontrado na literatura para a seleção de múltiplas características. Neste estudo, demonstramos a eficiência da Soma do Índice de Variáveis Padronizadas (SSV) para a seleção de múltiplas características em tabaco. O método foi avaliado usando uma coleção de treze linhagens parentais e seus híbridos oriundos de um esquema dialélico. Os híbridos, as linhagens parentais e as testemunhas foram avaliados em dois locais. As características avaliadas foram produtividade (YLD), índice geral de qualidade (IGQ), relação talo/ lâmina, porcentagem total de alcalóides e porcentagem total de açúcares. Consideramos os pesos para o indíce de acordo com a importância econômica de cada característica: 0,4 para YLD, 0,3 para GQI e 0,1 para os demais caracteres. O índice SSV mostrou-se eficiente e fácil de interpretar, podendo ser utilizado para se ter ganho genético para quase todos os caracteres na direção desejada. A capacidade geral de combinação (CGC) explicou a maior parte da variação do índice na análise dialélica. A estimativa de heterose média foi de $2,02 \%$. Algumas combinações de híbridos exibiram níveis de heterose maiores que 10\%, indicando que uma maior atenção pode precisar ser dada à comercialização de híbridos F1.
\end{abstract}

Termos para indexação: Melhoramento de plantas; genética quantitativa; heterose. 
CARVALHO, B. L. et al.

\section{INTRODUCTION}

A new cultivar will only be widely adopted if it meets the requirements of producers, industry, and consumers. These players have very different needs and their interests may not necessarily coincide in many cases. A difficulty therefore faced by plant breeders is that selection is hardly ever directed for a single trait. In the case of tobacco, numerous correlated traits are important, making development of new cultivars improved for multiple traits challenging.

Several breeding strategies have been outlined for simultaneous selection of multiple traits. First, tandem involves selection for one trait at a time until each trait is improved to desirable level. Second, independent culling involves simultaneous, but independent, selection for multiple traits. In addition, selection based upon a numerical index value can be used, whereby important traits are weighted and the index is calculated based upon a linear function of the traits being considered. The literature suggests that maximum selection efficiency can be observed by construction of a selection index (Falconer; Mackay 1996; Bernardo, 2020).

For tobacco, little published information exists relating to selection for multiple traits based upon calculated index values. Some estimates of negative trait correlations exist for tobacco, which can complicate the efforts of the plant breeder. However, these estimates were predominantly obtained under temperate climate conditions (White; Pandeya; Dirks 1979; Lewis, 2006). In addition, the importance of these associations may vary amongst varietal groups.

Although tobacco is typically considered an autogamous plant, the generation of commercial $\mathrm{F}_{1}$ hybrids can be viewed as desirable even though heterosis levels are of low magnitude for this species. Breeding programs already carry out manual hybridization to combine traits of interest present in different lines. Cytoplasmic male sterility facilitates hybrid seed production and also varietal protection for the originator of the variety. Therefore, diallel crossing schemes can be used to identify lines with good combining ability (Ramalho et al., 2012). Even though diallel crossing experiments have been frequently reported in the past (Matzinger; Wernsma; Ross, 1971; Butorac; Beljo; Gunjaca, 2004), multi-trait analysis of such data is not highly reported. Furthermore, no report has been found of diallel analysis involving a selection index for any species.

There are numerous methodologies for application of selection indices been the most efficient called the optimum index or the Smith-Hazel index (Bernardo, 2020). It has as a restriction, however, the estimation of genetic and phenotypic variances and covariances with high accuracy, which it is not always possible in practice. Furthermore, this index can only be applied when the effect of parents is considered random. This is rare in the case of diallel, because the parents used in the crosses are usually only those previously identified as being superior. For choice of a selection index, one of the most important aspects that influence the breeder's decision is the simplicity of application and interpretation, and the ability to produce results that are compatible with the requirements of the breeding program. One of the alternatives which fulfill this condition is the Sum of the Standardized Variables Index (SSV). The methodology was initially utilized by Lima et al. (2015) and has since gained some popularity. The present study was carried out with the objective of assessing the efficiency of SSV selection indices involving some important traits in tobacco and, at the same time, evaluates combing ability for measured traits from diallel crosses of flue cured tobacco inbred lines.

\section{MATERIAL AND METHODS}

All possible crosses amongst 13 Flue Cured Virginia (FCV) parental lines were made in half-diallel fashion and 72 hybrid combinations were obtained. The parental lines, derived hybrids, and 15 checks were evaluated using a $10 \times 10$ triple lattice design, in two locations in southern Brazil: a field experiment station, located in Mafra, State of Santa Catarina; and a private tobacco farm situated in the county of Ribeirãozinho, State of Santa Catarina.

Experimental units consisted of single 10-plant plots with $1.2 \mathrm{~m}$ between-row spacing and $0.5 \mathrm{~m}$ plant spacing. Crop management practices were those typically used for tobacco production within the region. The following traits of economic importance were assessed: yield (YLD) in $\mathrm{kg} / \mathrm{ha}$, by weighing the total of leaves of the plot after curing; general quality index (GQI), which is a classifying index that considers the position of the leaf on the plant, leaf shine intensity, color, maturity, oiliness and body. It is expressed as a percentage relative to the standardized ideal; cured leaf stem to lamina ratio (SLR), calculated as the percent of leaf constituted by midveins; percent total sugars (SUG) for cured leaves; and percent total alkaloid (ALK) of cured leaves.

The phenotypic correlations between measured traits were using traits means according to methodology presented by Steel, Torrie and Dickey (1996). 
The estimate of the selection indices was obtained for the SSV index. For this, the variables were first standardized per plot inside each repetition, having using the following estimate:

$Z_{i j l}^{k}=\frac{x_{i j l}^{k}-\bar{x}_{i j}^{k}}{\delta_{j l}^{k}}$

Where, $Z_{i j l}$ is the standardized variable of treatment $i$, in replication $j$, in location $l$, for trait $k ; X_{i j l}$ is the observation of treatment $i$, in replication $j$, in location $l$, for trait $k$; $\bar{X}_{i j}$ is the general mean of the treatments of replication $j$, in location $l$, for trait $k$; $\delta_{i j}$ is the standard deviation of replication $j$, in location $l$, for trait $k$;.

For measured traits where reductions are desired (SLR, SUG, and ALK) the generated values were multiplied by -1 . In this way the criterion is the same for all traits (i.e. the higher the value, the better). As the standardized variable has a mean of zero, negative and positive values occur, and a constant of 5 was therefore added to facilitate data analysis. The variables were then summed for each observation to obtain SVV index values. A weight was assigned to each trait based on their individual economic and commercial importance ( 0.4 for YLD; 0.3 for GQI; and 0.1 for SLR, SUG, and ALK).

Analyses of variance were applied to the SSV data according to Steel, Torrie and Dickey (1996). Diallel analyses were performed for the hybrids and parents adopting the fixed model method II of Griffing (1956), by location and across location:

$y_{i k}=m+g_{i}+g_{k}+s_{i k}+e_{i k}^{-}$

where $y_{i k}$ is the mean value of the diallel cross between the parents $i$ and $k ; m$ is a constant, that in this case represents the general means of the treatments of the diallel; $g_{i}$ and $g_{k}$ are the effects of the general combining ability of the $i$-eth and $j$-eth parent, respectively; $s_{i k}$ is the effect of the specific combining ability for the cross between parents $i$ and $k$ and $e_{i k}^{-}$is the mean experimental error, where $e \cap N\left(0, \sigma^{2}\right)$.

The effects of general and specific combining abilities $\left(g_{i}, g_{k}\right.$ and $\left.s_{i k}\right) \widehat{\beta}$ were estimated by the leastsquares method (unbalanced data). Thus, the solutions were obtained based on the equation $\hat{X} X \hat{\beta}=\hat{X} Y$, where $X$ : model matrix and $Y$ : mean phenotypic data.

Heterosis $(h)$ was estimated using the adjusted means of the treatments involved in the diallel. The mean heterosis $\left(h_{(\%)}\right)$ is obtained by the equation:
$\bar{h}_{(\%)}=[(\bar{H}-\bar{P}) / \bar{P}] 100$

where $\bar{H}$ : hybrids means and $\bar{P}$ : parents mean.

The parental vs hybrids contrast was used to determine whether the mean heterosis was different from zero.

\section{RESULTS AND DISCUSSION}

As already mentioned above, the objective of any plant breeding program is to generate cultivars that meet the requirements of farmers, industry, and consumers. Breeders must therefore usually take into consideration multiple traits during the selection process. Under this condition, application of a selection index may be the most efficient method for simultaneous multi-trait selection (Céron-Rojas; Crossa 2018; Bernardo, 2020). When establishing an index, it is necessary to know the association among the traits considered. Table 1 shows the phenotypic correlations coefficients $(r)$ among the traits pair wise, averaged over both environments. Even for trait combinations where $r$ was significant, the magnitudes were not very high. The highest estimates were between GQI and SUG $(r=0.53)$ and GQI and SLR $(r=-0.53)$, making the application of SSV indices favorable. Moreover, the absence of high magnitude correlation is an indicator of no restriction in the selection of each trait.

Table 1: Estimates of correlation between traits means, from the diallel involving 13 parental lines of tobacco from the FCV varietal group. Estimates obtained from the mean of two locations, were yield (YLD), general quality index (GQI), steam by leaf lamina ratio (SLR), total alkaloids (ALK), total sugar content (SUG).

\begin{tabular}{|c|c|c|c|c|c|}
\hline Traits & YLD & GQI & SLR & ALK & SUG \\
\hline YLD & & -0.15 & $0.33 * \star$ & -0.07 & 0.03 \\
\hline GQI & & & $-0.53^{* *}$ & $0.43^{* *}$ & $0.53 * *$ \\
\hline SLR & & & & $-0.18^{*}$ & $-0.47^{* *}$ \\
\hline ALK & & & & & 0.07 \\
\hline
\end{tabular}

In this case, an important decision was the choice of weights for the trait analysis. In tobacco, yield is extremely important because economic revenue generated by growers is highly dependent upon yields. The GQI is also extremely important because it is directly linked to the quality of the end product. Add to that, the larger the 
GQI, the higher the price paid to the grower. Thus, this index impacts the producer and consumer and therefore high weight should be given to this trait in the index. The correlation between the most important variables (YLD and GQI) was not significant, suggesting no association between them (Table 1).

Higher values for SLR are undesirable for purchasers of cured tobacco leaf because only a small percentage is used in manufacturing of tobacco products. However, this trait is considered secondary in selection, mainly because line/hybrids with larger leaves, that are more productive, also tend to have thicker leaf veins for better support. This fact was proven by the positive correlation estimate between SLR and YLD. An alternative possibility is that superior yield of better lines was due to the increase in the number of leaves, and not due to the size of the leaves.

The requirement for ALK is that the lines/hybrids be within a desirable range $(2.5 \%-3.5 \%)$. It is important to note that this range is an average, since the alkaloid rates can vary depending on the leaf positions in the plant and maturity level at harvesting (Henry; Vann; Lewis, 2019). As most of the lines accumulated alkaloids close to, or above, $3.5 \%$, the index was applied to reduce this component. Positive and significant correlation was observed between ALK and GQI. For new flue-cured cultivars to be commercialized in Brazil, it is desired to increase GQI and reduce ALK, so this correlation is unfavorable to the breeder. The correlation was not high, however, so it should be possible to produce lines/hybrids with increased GQI and reduced ALK. It is pointed out that, contrary to the situation in Brazil, in several other countries (e.g., the United States, Venezuela and others), one of the major challenges is increasing YLD while maintaining ALK at acceptable levels, because cultivars tend to present low ALK content when YLD is high (Lewis 2006). A negative correlation was observed between ALK and SLR, which is also unfavorable as a decrease in both is desired. Similarly, as correlation magnitudes were low, materials with low ALK and SLR might easily be obtained.

As already mentioned, SUG is important for the FCV group. This component alters the taste perception of cigarettes and for this reason was considered in the index. Specialists indicate that $12 \%$ would be the ideal concentration to the industry for FCV, and thus the index was applied to reduce deviation based on this concentration.

There are many methodologies to obtain selection indexes involving several characters (Fernandes et al., 2018, Bernardo, 2020). However, it is important to select one that is easy to interpret, such as the Sum of the Standardized Variables (SVV) Index. A good index is the one that enables choice of the best line/cultivar with the most phenotypic expression as possible, in the desired direction, for all traits of interest. Besides of its practicality and simplicity in application, the SSV index presented superiority in hybrid selection for all traits assessed. Through the application of the SSV index, it is possible to obtain gains for all traits simultaneously.

For example, in the case of the hybrid with the best estimate ( $1 \times 7$ and $1 \times 5)$, figures $1-A$ and $1-B$ exhibit phenotypes that resemble a "full- ball", and most of the traits had expression levels that were above the means. In the other hand, hybrid 2x11 (Figure 1-C) resembles that of a "deflated-ball". It can be seen, that from the six evaluated traits, four of them are below the mean (Table 4 and Figure 1).

Significant differences were detected $(\mathrm{P} \leq 0.01)$ among treatments in the individual analysis of variance (data not shown). The accuracy estimates were all of high magnitude. In the joint analysis, the source of variation for 'treatments' and 'treatments $\mathrm{x}$ location $(\mathrm{TxL})$ ' were significant $(\mathrm{P} \leq 0.05)$. This means that the performance of the genotypes was not consistent between the two
A)

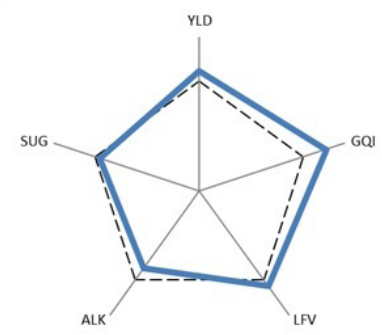

B)

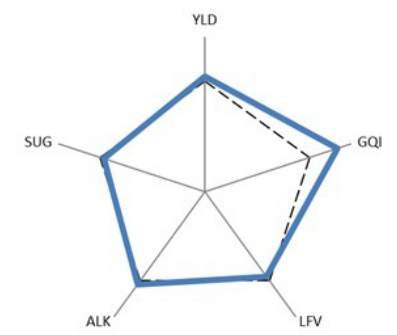

C)

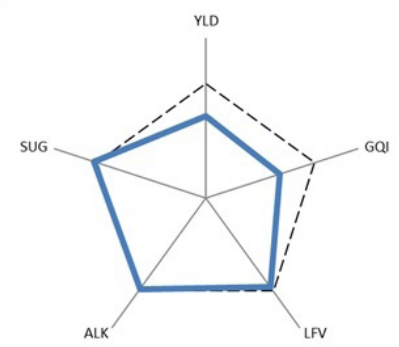

Figure 1: Standardized variables of the four superior hybrids ( $A$ and $B$ ) and one inferior hybrid (C) for SSV indices. The dotted line refers to the general mean. A) SSV: hybrid 1x7; B) SSV: hybrid 1x5; C) SSV: hybrid 2x11. 
locations. It is important to point out that there are more than 150 thousand tobacco producers in the southern region of Brazil (Associação dos Fumicultores do Brasil - AFUBRA, 2020), and they differ in several aspects including planting date, soil type, and management technology. Consequently, it is practically impossible to recommend a cultivar specifically adapted for each grower. The best option to mitigate the effect of the interaction is selection based on the mean of the environments (Dudley, 1997; Ferreira et al., 2015). For this reason, it was chosen to concentrate the discussion of the results based on the mean of the two environments.

The parental materials chosen for this study are the product of several years of breeding. It seems that the program has been successful because, in most cases, the mean of the treatments of the diallel $(\mathrm{H}+\mathrm{P})$, involving the lines and the hybrid combinations among them, was superior to the mean of the checks (C), which are lines available on the market for commercial plantations. When the traits were assessed independently the results converge. That is, for all the traits, the diallel treatments presented means larger than the checks, demonstrating the potential of the lines to a breeding program (Table 2).

Table 2: Summary of the joint analysis of variance across locations and diallel analysis by the Griffing (1956) model, method II. Selection index data of FCV tobacco.

\begin{tabular}{|c|c|c|}
\hline Source of Variation & DF & $\mathrm{F}$ \\
\hline Treatment $(\mathrm{T})$ & 99 & $1.92^{* * *}$ \\
\hline Parents (P) & 12 & $1.93^{* *}$ \\
\hline Hybrids $(\mathrm{H})$ & 71 & $1.60^{* * *}$ \\
\hline H vs P & 1 & $3.45^{\star}$ \\
\hline GCA & 12 & $2.92^{\star \star \star}$ \\
\hline SCA & 72 & 1.13 \\
\hline Checks (C) & 14 & $3.55^{* * *}$ \\
\hline$(\mathrm{H}+\mathrm{P})$ vs $\mathrm{C}$ & 1 & $3.40^{*}$ \\
\hline$T \times L$ & 99 & $1.55^{\star * *}$ \\
\hline Check mean & & 4.92 \\
\hline Diallel mean & & 5.02 \\
\hline Parents mean & & 4.93 \\
\hline Hybrids mean & & 5.03 \\
\hline Acuraccy $\left(r_{\mathrm{gg}}\right)^{\mathrm{a}}$ & & 0.69 \\
\hline
\end{tabular}

Although diallel crosses are widely used in plant breeding in many species (Qian et al., 2016; Seyyed-Nazari et al., 2016; Abigail; Ramsey, 2019; Barata et al., 2019), no report was found of its use to assess several characteristics simultaneously using an index. Considering the mean of the two locations, the two parents with the highest mean were numbers 3 and 6 . The best performance hybrids were combinations $1 \times 5$ and $1 \times 7$. The significant contrast $\mathrm{H}$ vs $\mathrm{P}$ indicates that the mean heterosis was different from zero, although of low magnitude (2.2\%). Different hybrid combinations exhibited heterosis levels varying from $-22.4 \%$ (Parent $2 \times$ Parent 11 ) to $14.8 \%$ (Parent $1 \mathrm{x}$ Parent 5). It is important to highlight that 19 of 72 hybrid combinations had negative heterosis estimates. The hybrid combinations with higher means were not those with the highest heterosis $h_{i j}$, by percentage (Table 3 ).

The mean observed heterosis level for the index was different from zero (Table 2). This fact is also in agreement with the results obtained for each trait independently (data not shown). The use of hybrid seeds in tobacco has been adopted by companies to combine traits present in different lines and to introduce male sterility to protect the cultivars developed. Thus, even with low heterosis, the use of hybrids should be encouraged to increase gains. For this diallel crossing scheme reported here, we were able to demonstrate the viability of developing hybrids when selecting for several traits simultaneously.

There were significant differences for GCA, but not for SCA (Table 2). Only the parents 1, 2, 3, 5, and 8 showed positive $\hat{g}_{i}$ estimates. The heterosis associated to each parent $(\mathrm{H})$ was also assessed, that is, the mean heterosis of hybrids to which the referred parent was common (Table 3). The largest parental heterosis was in parents 5 and 12 . Two of the $\mathrm{H}$ estimates were negative, for parents 2 and 10 .

Since the mean performance of the $F_{1}$ of a hybrid is given by: $F_{1}=\frac{P_{1}+P_{2}}{2}+h$, and the hybrid performance depends on the mean of the parents $\frac{P_{1}+P_{2}}{2}$ and the heterosis (h) between them. In the present study, the mean SVV for all hybrids was 5.03, while the means for the parental materials was 4.93. It can be therefore be inferred that the hybrid performance depended predominantly on the per se performance of the lines, which is common in self-pollinated species (Ramalho et al., 2012; Bernardo 2020). In the case of cross-pollinated species, especially corn, the mean heterosis is generally of high magnitude. However, there is evidence that over time, hybrid performance has increased due to the improvement in the performance of the parental inbred lines rather than an increase in heterosis (Troyer; Wellin, 2009). 
Table 3: Selection index means of hybrids above diagonal, parent (Par.) mean at diagonal, hybrid parental means heterosis $\left(\mathrm{h}_{\mathrm{m}}\right)$, in percentage, below diagonal and estimates of general combination capacity $\left(\hat{g}_{i}\right)$. Indices data obtained from mean of two locations in FCV tobacco.

\begin{tabular}{cccccccccccccccc}
\hline Par. & 1 & 2 & 3 & 4 & 5 & 6 & 7 & 8 & 9 & 10 & 11 & 12 & 13 & $\left(\hat{g}_{i}\right)^{a}$ \\
\hline 1 & $\mathbf{5 . 0 5}$ & 5.36 & 5.11 & 4.43 & 5.45 & 5.39 & 5.45 & 5.30 & 5.13 & 5.23 & 5.13 & 5.32 & 4.85 & 0.20 \\
2 & 4.72 & $\mathbf{5 . 1 8}$ & 5.09 & 4.91 & 5.16 & 5.23 & 5.06 & 4.79 & 5.15 & 5.24 & 3.93 & - & - & 0.01 \\
3 & -1.62 & -3.16 & $\mathbf{5 . 3 4}$ & 5.02 & 5.09 & 5.28 & 5.26 & 5.36 & 5.22 & 5.01 & 5.09 & 5.10 & 5.17 & 0.14 \\
4 & -10.9 & -2.51 & -1.95 & $\mathbf{4 . 8 9}$ & 4.98 & 5.00 & 4.81 & 5.00 & 4.77 & 4.99 & 4.95 & 5.07 & 5.14 & -0.12 \\
5 & 14.8 & 7.37 & 4.04 & 6.72 & $\mathbf{4 . 4 3}$ & 5.12 & 4.95 & 4.78 & 4.84 & 4.51 & 5.25 & 5.04 & 5.04 & -0.03 \\
6 & 4.79 & 0.66 & -0.05 & -1.14 & 6.14 & $\mathbf{5 . 2 2}$ & 5.07 & 5.03 & 5.08 & 4.56 & 5.11 & 4.98 & - & 0.11 \\
7 & 11.7 & 2.51 & 4.76 & 0.35 & 8.41 & 2.13 & $\mathbf{4 . 7 0}$ & 4.96 & 4.85 & 5.14 & 5.15 & 4.96 & 4.67 & -0.04 \\
8 & 7.52 & -3.89 & 5.68 & 3.26 & 3.43 & 0.29 & 4.32 & $\mathbf{4 . 8 0}$ & 4.87 & 5.13 & 5.27 & 5.24 & 5.23 & 0.04 \\
9 & 2.66 & 1.87 & 1.63 & -2.99 & 3.3 & 0.1 & 0.59 & 0.07 & $\mathbf{4 . 9 3}$ & 4.63 & 5.23 & 5.09 & 5.04 & -0.02 \\
10 & 3.52 & 2.33 & -3.63 & 0.37 & -4.96 & -11.4 & 5.35 & 4.06 & -7.41 & $\mathbf{5 . 0 6}$ & - & 4.74 & 4.91 & -0.14 \\
11 & 2.61 & -22.4 & -1.08 & 0.71 & 12 & 0.43 & 6.72 & 8.09 & 5.93 & - & $\mathbf{4 . 9 5}$ & - & - & -0.06 \\
12 & 11.6 & - & 3.84 & 8.18 & 12.9 & 2.65 & 7.87 & 12.8 & 8.05 & -0.66 & - & $\mathbf{4 . 4 9}$ & 4.84 & -0.06 \\
13 & -3.24 & - & 0.27 & 4.15 & 7.21 & - & -3.6 & 7.06 & 1.68 & -2.07 & - & 2.24 & $\mathbf{4 . 9 8}$ & -0.05 \\
\hline
\end{tabular}

$\operatorname{arar}\left(\hat{g}_{i}\right)=0.00598 ; \operatorname{Var}\left(\hat{g}_{i}-\hat{g}_{i^{\prime}}\right)=0.00042$.

How does one explain the negative heterosis estimates for some hybrid combinations? Heterosis, in principle, is a function of the allelic interaction of dominance $(d)$ and the divergence of parents (Falconer; Mackay 1996). The $d$ can have a positive or negative effect on the phenotypic expression of the character. However, it is difficult to explain the occurrence of positive and negative $h$ at the same time. Thus, $d$ alone is not sufficient to explain the occurrence of positive and negative heterosis for the same character (Goodnight, 1995). The hypothesis to explain this type of heterosis is the occurrence of gene interaction, epistasis, of the additive $\mathrm{x}$ additive type; (Van Ginkel; Ortiz, 2018).

The five best-performing hybrids are presented in Table 4. Four of them involve Parent 1 as a parent (Parent 1 has the largest $\mathrm{g}_{\mathrm{i}}$ ). The fifth hybrid involves Parent 3, which has the second largest $g_{i}$. However, we need to emphasize that among the two lowest-performing hybrids, one involves Parent 1 . It is important to verify that the indices classify the treatments in the direction which the breeders desire. For yield, the classification was all in the desired direction. Increases in GQI are also desired, which is what occurred in three of the five hybrids. For SLR, the objective is to reduce the value and that was observed in only one case. However, for those that went in the opposite direction, the magnitude was low in percentage. In the case of SUG, a deviation was estimated in relation to $12 \%$, the intended value, that is, the smaller the deviation the better. There were only two cases in the desired direction, $1 \times 7$ and 1x5. Reduction in ALK was required so that the selected hybrids were within the ideal range. In this case only one hybrid presented alkaloid levels that were above the mean.

Table 4: Deviation from the mean of the traits yield (YLD), general quality index (GQI), steam by leaf lamina ratio (SLR), total sugar content (SUG), and total alkaloids (ALK), of the five best and two worst hybrids based on selection indices (Index). Values in grey are below the mean.

\begin{tabular}{ccccccc}
\hline Hybrid & Index & YLD & \multicolumn{1}{c}{ GQI } & \multicolumn{1}{c}{ SLR } & SUG & \multicolumn{1}{c}{ ALK } \\
\hline $1 \times 7$ & 5.45 & 4.58 & 19.63 & 1.16 & -3.67 & -12.12 \\
$1 \times 5$ & 5.45 & 1.38 & 24.52 & -6.94 & -3.27 & -5.03 \\
$1 \times 6$ & 5.39 & 5.40 & 1.15 & 7.00 & 7.98 & -2.36 \\
$3 \times 8$ & 5.36 & 15.66 & -3.52 & 3.21 & 1.12 & 22.79 \\
$1 \times 2$ & 5.36 & 9.91 & -1.00 & -0.04 & 4.21 & -26.88 \\
& & & $\ldots$ & & & \\
$1 \times 4$ & 4.43 & -25.39 & 7.83 & -12.69 & 4.10 & -5.88 \\
$2 \times 11$ & 3.93 & -24.54 & -27.43 & 6.33 & 3.95 & -44.28 \\
\hline
\end{tabular}


The general combining ability $\left(\hat{g}_{i}\right)$ is the function of performance per se of the lines $\left(p_{\mathrm{i}}\right)$ and also of the mean heterosis of that parent in all the hybrid combinations $\left(h_{\mathrm{i}}\right)$, i.e., $\hat{g}_{i}=h i-\frac{1}{2} \bar{p}_{i}$ (Cruz; Carneiro; Regazzi, 2014). If the correlation between the mean and the combining ability of a specific line was 1.0, only the line mean would be enough to explain the $\left(\hat{g}_{i}\right)$ magnitude. It must be emphasized that the perfect correlation $(r=1)$ between the mean of the parents and the estimate of the general combining ability only occurs when the allele frequency, for a given locus, is equal to 0.5 , or if there is no allele interaction of dominance (Vencovsky; Barriga, 1992). If it were just a two-parent crossing, one could imagine that the allele frequency, for loci for which the parents are contrasting, would be 0.5. However, considering the diallel crossing of several parents, the chance of the allelic frequency being 0.5 is very remote. Thus, dominance influences the estimate of $\hat{g}_{i}$ even though it is of small magnitude, as normally occurs in autogamous plants (Ramalho et al., 2012; Bernardo, 2020). These results show that, in breeding programs, the application of parental performance per se alone was not sufficient to obtain good hybrids, as the lines must also be divergent (Falconer; Makcay, 1996). To assess this divergence, the hybrid combinations must be assessed in the field or by using genomic data (Labroo; Studer; Rutkoski, 2021). It should be highlighted, however, that the "per se" performance of parents is the most expressive contribution, as already mentioned. Emphasizing what has already been said, tobacco breeders should initially carry out a line selection program with a view to select for "per $s e$ " performance. In this way, one can even capitalize on part of the heterosis through the selection of lines with good homozygous genetic combinations that contribute to positive additive $\mathrm{x}$ additive epistasis (Jiang et al., 2017; Van Ginkel; Ortiz, 2018).

Subsequently, the best lines must be evaluated in a hybrid development program, aiming at the identification of hybrids with complementary allelic pairs (Tamta; Sing, 2018). In this situation, the average of the hybrid will be higher because the parents already have high average, $\frac{P_{i}+P_{j}}{2}$, and the heterosis will be different from zero. It was evident that, in the application of this approach, the selection of several characters can and must be carried out at the same time using the standardized selection index.

\section{CONCLUSIONS}

The SSV index proved to be efficient and easy to interpret, and could be used to generate genetic gain for almost all characters in the desired direction. General combining ability (GCA) explained the larger part of the variation of the index in the diallel analysis. The mean heterosis estimate was $2.02 \%$. Some hybrid combinations exhibited heterosis levels greater than $10 \%$, indicating that increased attention might need to be given to commercialization of $\mathrm{F}_{1}$ hybrids.

\section{ACKNOWLEDGMENTS}

This work was supported by BAT Brazil, who provided the data and financial resources. It was financed in part by the Coordenação de Aperfeiçoamento de Pessoal de Nível Superior - Brasil (CAPES) - Finnacial Code 001. This work was supported by the Conselho Nacional de Desenvolvimento Científico e Tecnológico - CNPq / MCTIC, through grant of productivity to the authors. Special thanks for Carlos Eduardo Pulcinelli for his distinguished collaboration to this paper.

\section{REFERENCES}

ASSOCIAÇÃO DOS FUMICULTORES DO BRASIL - AFUBRA. Fumicultura no Brasil. 2020. Available in: <https://afubra. com.br/fumicultura-brasil.html>. Access in: July, 27, 2021.

ABIGAIL, D. B.; RAMSEY, S. L. Heterosis in flue-cured tobacco and its utility in predicting transgressive segregation within derived populations of inbred lines. Crop Science, 59(3):957-967, 2019.

BARATA, N. M. et al. A new partial diallel model adapted to analyze reciprocal effects in grain yield of maize. Crop Breeding and Applied Biotechnology, 19(1):2230, 2019.

BERNARDO, R. Breeding for quantitative traits in plants. 3. ed. Woodbury: Stemma Press. 2020. 422p.

BUTORAC, J.; BELJO, J.; GUNJACA, J. Study of inheritance of some agronomic and morphological traits in burley tobacco by graphic analysis of diallel cross. Plant Soil Environment, 50(4):162-167, 2004.

CÉRON-ROJAS, J. J.; CROSSA, J. Linear selection indices in modern plant breeding. Cham: Springer, 2018. 256p. 
CRUZ, C. D.; CARNEIRO, P. C. S.; REGAZZI, A. J. Modelos biométricos aplicados ao melhoramento genético. v. 2, 3 . ed. Viçosa: UFV, 2014. 668p.

DUDLEY, J. W. Quantitative genetics and plant breeding. Advances in Agronomy, 59:1-23, 1997.

FALCONER, D. S.; MACKAY, T. F. C. Introduction to quantitative genetics. 4th ed. Malaysia: Pearson, 1996. 464p.

FERNANDES, S. B. et al. Efficiency of multi-trait, indirect, and trait-assisted genomic selection for improvement of biomass sorghum. Theoretical and Applied Genetics, 131:747-755, 2018.

FERREIRA, R. A. D. C. et al. Implications of the number of years assessment on recommendation of common bean cultivars. Plant Breeding, 134(5):599-604, 2015.

GOODNIGHT, C. J. Epistasis and the increase in additive genetic variance: implications for phase 1 of Wright's shifting-balance process. Evolution, 49(3):502-511, 1995.

GRIFFING, B. Concept of general and specific combining ability in relation to diallel crossing systems. Australian Journal of Biological Sciences, 9(4):463-493, 1956.

HENRY, J. B.; VANN, M. C.; LEWIS, R. S. Agronomic practices affecting nicotine concentration in flue-cured tobacco: $A$ review. Agronomy Journal, 111(6):3067-307, 2019.

JIANG, Y. et al. A quantitative genetic framework highlights the role of epistatic effects for grain-yield heterosis in bread wheat. Nature Genetics, 49:1741-1746. 2017.

LABROO, M. R.; STUDER, A. J.; RUTKOSKI, J. E. Heterosis and hybrid crop breeding: A multidisciplinary review. Frontiers in Genetics, 12:643761, 2021.

LEWIS, R. S. Identification of germplasm of possible value for confronting an unfavorable inverse genetic correlation in tobacco. Crop Science, 46(4):1764-1771, 2006.
LIMA, D. C. et al. Breeding common bean populations for traits using selection index. Scientia Agricola, 72(2):132-137, 2015.

MATZINGER, D. F.; WERNSMAN, E. A.; ROSS, H. F. Diallel crosses among burley varieties of Nicotiana tabacum L. in the F1 and F2 Generations. Crop Science, 11(2):275-279, 1971.

QIAN, Y. L. et al. Genetic analyses of the major and minor locus groups of bacterial wilt resistance in tobacco using a diallel cross design. Genetics and Molecular Research, 15(1): 15017223, 2016.

RAMALHO, M. A. P. et al. Aplicações da genética quantitativa no melhoramento de plantas autógamas. Lavras: UFLA, 2012. 522p.

SEYYED-NAZARI, R. et al. Diallel analysis for estimation of genetic parameters in oriental tobacco genotypes. Genetika, 48(1):125-137, 2016.

STEEL, R. G. D.; TORRIE, J. H.; DICKEY, D. A. Principles and procedures of statistics: A biometrical approach. 3. ed. New York: McGraw-Hill, 1996. 666p.

TAMTA, S.; SINGH, J. P. Heterosis in tomato for growth and yield traits. International Journal of Vegetable Science, 24(2):169179, 2018.

TROYER, A. F.; WELLING, E. J. Heterosis decreasing in hybrids: Yield test inbreds. Crop Science, 49(6):1969-1976, 2009.

VAN GINKEL, M.; ORTIZ, R. Cross the best with the best, and select the best: HELP in breeding selfing crops. Crop Science, 58(1):17-30, 2018.

VENCOVSKY, R.; BARRIGA, P. Genética biométrica no fitomelhoramento. 1. ed. Ribeirão Preto: Sociedade Brasileira de Genética, 1992. 496p.

WHITE, F. H.; PANDEYA, R. S.; DIRKS, V. A. Correlation studies among and between agronomic, chemical, physical and smoke characteristics in flue-cured tobacco (Nicotiana tabacum L.). Canadian Journal of Plant Science, 59(1):111-120, 1979. 